\title{
Bleaching Patterns of Four Species of Caribbean Reef Corals
}

\author{
W. K. FITT AND M. E. WARNER \\ Institute of Ecology, University of Georgia, Athens, Georgia 30602
}

\begin{abstract}
Bleaching of reef corals, involving loss of symbiotic algae (= zooxanthellae), loss of algal pigments, or both, has been linked to temperature stress. In this study the effects of high temperature and light on zooxanthellae living in the Caribbean reef corals Montastrea annularis, M. cavernosa, Agaricia agaricites, and A. lamarcki were studied. Pieces of coral colonies were incubated at ambient seawater temperature $\left(26^{\circ} \pm 1^{\circ} \mathrm{C}\right)$, and at $30^{\circ}, 32^{\circ}$, and $34^{\circ} \mathrm{C}$. Symbiotic algae from M. annularis, a species of coral from the forereef that commonly bleaches, showed the following sequence of events when exposed to natural light at $32^{\circ} \mathrm{C}$ : loss of photosynthetic potential measured as fluorescence yield, corresponding reduction of both oxygen production per zooxanthella and P:R (photosynthesis:respiration) ratio, and subsequent reduction in density of algae in relation to surface area of the coral. These parameters were not significantly reduced and no deaths occurred for $M$. annularis or any other coral species maintained at $26^{\circ}$ or $30^{\circ} \mathrm{C}$. However, the sequence of events was condensed to less than $24 \mathrm{~h}$ when $M$. annularis was subjected to $34^{\circ} \mathrm{C}$ seawater, except that there was little if any reduction in algal density before tissue-sloughing and death occurred between 10 and $24 \mathrm{~h}$. Loss of significant amounts of chlorophyll $a$ per alga was not evident for any corals except those maintained at $34^{\circ} \mathrm{C}$ longer than $10 \mathrm{~h}$. In contrast, symbiotic algae in $\mathrm{M}$. cavernosa, a species that rarely bleaches in nature, showed only slight reductions in photosynthesis and fluorescence yield, and no significant loss of algal cells or chlorophyll $a$, when maintained in seawater at $32^{\circ} \mathrm{C}$ for 2 days. Thus zooxanthellae in $M$. cavernos $a$ appeared to be less affected by sublethal high-temperature stress. Similar contrasting patterns of bleaching were seen in zooxanthellae from the plating coral Agaricia lamarcki, which often bleaches
\end{abstract}

Received 6 December 1994; accepted 14 September 1995 during the late summer and fall, compared with zooxanthellae from A. agaricites, a coral which bleaches less frequently. In addition, $M$. annularis exposed to sublethal high temperatures and ambient light bleached faster than those kept in dimmer light, supporting past field observations suggesting that light energy is an important component of bleaching in nature. When $M$. annularis was exposed to different wavelengths of natural light at $32^{\circ} \mathrm{C}$, the fluorescence yield declined more quickly in the presence of higher energy UV-A and blue light than with other photosynthetically active radiation. Natural levels of UV-B had little effect in this study. These data suggest that the patterns of bleaching seen in nature may be at least partially explained by different tolerances of the symbiotic algae in the corals, and that light plays a significant role in bleaching.

\section{Introduction}

Two major ecological events during the last decade focused the attention of coral reef researchers on the susceptibility of corals and associated reef organisms to the potentially devastating effects of elevated seawater temperatures. The first was the 1982-1983 El Niño Southern Oscillation (ENSO), during which many hard and soft corals from the Great Barrier Reef, the Central Pacific, and eventually the Eastern Pacific bleached as seawater temperatures rose $2^{\circ}-6^{\circ} \mathrm{C}$ above normal (Glynn, 1983, 1984; Oliver, 1985; Harriot, 1985; Fisk and Done, 1985; Coffroth et al., 1990; Glynn and D'Croz, 1990). Subsequent coral death was common: up to $97 \%$ of the species harboring symbiotic algae were reported dead on some reefs (Glynn and D’Croz, 1990).

The Caribbean-wide "bleaching event" of 1987 again drew attention to warm-water stress in the marine environment, this time coupled with concerns that global warming might be one of the causes (Williams and Williams, 1988). Though bleaching was extensive, total loss 
of zooxanthellae from coral tissues was rare, as was death of entire coral colonies (see references in Fitt et al., 1993; Porter and Meier, 1992). Most bleached corals recovered their normal coloration within a year (Szmant and Gassman, 1990; Fitt et al., 1993). The results of both of these events are consistent with the notion that corals and other associated invertebrates are living close to their physiological upper thermal limits during summer months, so that even the smallest increase in seawater temperature may have an effect if the exposure time is long enough (Coles et al., 1976).

Virtually all studies of bleaching support the supposition that summertime bleaching is at least partially linked to the high temperatures (e.g., Yonge and Nichols, 1931a; Jokiel and Coles, 1977; Jaap, 1979; Glynn, 1984; Lasker et al., 1984; Hoegh-Guldberg and Smith, 1989; Glynn and D'Croz, 1991; Gates et al., 1992; Jokiel and Coles, 1990; Fitt et al., 1993). Two of the best examples of the role of temperature involve laboratory experiments, one simulating El Niño conditions in the Eastern Pacific (Glynn and D'Croz, 1990) and the other mimicking the effects of the thermal discharge system of a power generator in Hawaii (Jokiel and Coles, 1977). Both studies clearly showed the immediate, adverse effects on corals of abnormally high temperatures $\left(\geq 32^{\circ} \mathrm{C}\right)$, as well as more subtle bleaching during long-term exposure to temperatures only $1^{\circ}-2^{\circ} \mathrm{C}$ above normal ambient (e.g., $30^{\circ} \mathrm{C}$ ).

The relative importance of other environmental factors on bleaching is more contentious. Low salinity and high levels of natural light sometimes show synergistic effects in connection with high temperatures near the limits of tolerance for corals (Coles and Jokiel, 1978; cf. HoeghGuldberg and Smith, 1989). In addition, high doses of ultraviolet light induce bleaching without increased temperature (Jokiel, 1980; Gleason and Wellington, 1993). Although the role of light in bleaching is interesting, little is currently known about the role of light quantity and quality, especially in relation to photosynthetic action spectra of the symbiotic algae. For instance, UV-B blocking compounds have been described and characterized (Dunlap and Chalker, 1986), and show the expected decrease in concentrations with depth (Dunlap et al., 1988). However, protection by these compounds from UV-A light ( $c a .320-400 \mathrm{~nm}$ ) is generally limited at wavelengths greater than $350 \mathrm{~nm}$, where photosynthetic pigments in zooxanthellae begin absorbing light (Jeffrey and Haxo, 1968; Dunlap et al., 1988). This leaves the coral and symbiotic algae exposed to longer UV-A wavelengths and blue light (ca. 400-450) (Dunlap et al., 1988), as well as to other photosynthetically active radiation (PAR).

One of the most perplexing aspects of coral bleaching is that some species seem to lose color frequently and quickly during bleaching events, whereas others never seem to bleach. For instance, the Caribbean reef-building coral Montastrea anularris is one of the first species to appear discolored during bleaching events, whereas $M$. cavernosa rarely bleaches (Jaap, 1979, 1985). Although differential tolerance of host tissue to environmental stress may explain these patterns, it is also possible that different species or types of zooxanthellae (see Trench, 1993) exhibit different tolerances to temperature and light ( $c f$. Fitt, 1985).

One explanation proposed for high-temperature bleaching is that the host digestive cells detach from the mesoglea, carrying zooxanthellae out of the coelenteron, in a fashion seen in cnidarians exposed to cold water stress (Gates et al., 1992). Other investigators have found that cultured zooxanthellae placed in temperatures equal to or higher than $32^{\circ} \mathrm{C}$ show decreased photosynthetic efficiency (Iglesias-Prieto et al., 1992); this observation suggests that the algae, and not just the host, are responsible for the breakdown of the symbiosis during bleaching. There is still no consensus as to which of the symbiotic partners is more affected by high temperature. In this study we address some of these issues by documenting the sequence of events occurring in zooxanthellae living symbiotically with four species of Caribbean reef corals, and show that both light quantity and quality can be important environmental factors in bleaching.

\section{Materials and Methods}

\section{Collection and maintenance of animals}

Intact colonies of the reef corals Agaricia agaricites, $A$. lamarcki, Montastrea annularis, and $M$. cavernosa were collected from a depth of $14-16 \mathrm{~m}$ on the forereef off the Discovery Bay Marine Laboratory in Jamaica in the early morning (0700-0800) in February and March of 1993 and 1994. Within $1 \mathrm{~h}$ of collection each colony was broken into eight pieces, each with a surface area of $5-10 \mathrm{~cm}^{2}$, and placed into one of four water-jacketed acrylic incubation chambers containing about 3.51 of seawater. The clear plastic chambers were exposed to ambient light; their open tops were covered with three layers of screen to reduce the maximum light intensities to slightly less those found at 14-16 m on the reef. Light intensities at noon on a cloudless day on the reef at $15 \mathrm{~m}$ were measured on three occasions and ranged between $500-600 \mu \mathrm{E} \mathrm{m}^{-2} \mathrm{~s}^{-1}$, maximum intensities measured in the chambers under the screen were $400-475 \mu \mathrm{E} \mathrm{m}^{-2} \mathrm{~s}^{-1}$. During the experiments, fresh unfiltered seawater flowed into the chambers at $c a .150 \mathrm{~m} \mathrm{~min}^{-1}$ and vigorous aeration from aquarium pumps and air stones kept the water well mixed. Ambient seawater temperatures were $26.0^{\circ} \pm 1.0^{\circ} \mathrm{C}$. Coral pieces were allowed to equilibrate in the chambers for 5-15 $\mathrm{min}$ at ambient temperature before the start of each experiment. Under ambient temperature and light, control 
pieces maintained in chambers showed no adverse or visible effects for at least 4 days.

\section{Experimental protocol}

Coral pieces were placed in one of four chambers, each starting out at ambient seawater temperature $\left(26.0^{\circ} \mathrm{C}\right.$ $\pm 1.0^{\circ} \mathrm{C}$ ). In three of the chambers, aquarium heaters were used to raise the temperature over a period of about $1 \mathrm{~h}$. Temperatures were kept at $30^{\circ}, 32^{\circ}$, and $34^{\circ} \mathrm{C} \pm 0.5^{\circ} \mathrm{C}$. A minimum of four replicate colonies were tested from each species. At least two pieces of each replicate colony were placed into each of the four chambers so that samples could be taken at different times. Coral pieces maintained at $26^{\circ}, 30^{\circ}$, and $32^{\circ} \mathrm{C}$ were processed at about 24 and $48 \mathrm{~h}$. Coral pieces exposed to $34^{\circ} \mathrm{C}$ were sampled $3-$ 5 times during the first 24 -h period. Pieces of coral were processed for physiological testing and biomass determinations as detailed below.

\section{Light quality and quantity experiments}

Pieces of six replicate heads of $M$. annularis used in experiments testing the effects of light quality and quantity were collected from a patch reef (1-2 m deep) off Key Largo, Florida. Coral pieces were placed in glass petri dishes in a $32^{\circ} \mathrm{C}$ temperature bath with aeration, where the seawater was changed at least every $4 \mathrm{~h}$ throughout the experiment. The quality and quantity of natural ambient light were adjusted with screens and glass cut-off filters (Melles Girot). Corals were exposed to one of the following conditions: natural light with no filters, natural light without UV-B (>320 nm), natural light without UV$A$ and $B(>395 \mathrm{~nm})$, or natural light without UV or blue light $(>495 \mathrm{~nm})$. Two layers of window screen covered the entire waterbath to reduce the maximum exposure level to slightly lower than that found in situ $\left(<700 \mu \mathrm{E} \mathrm{m}^{2} \mathrm{~s}^{-1}\right)$. Some coral pieces (control) were maintained under two layers of window screen without filters, but at $26^{\circ} \mathrm{C}$.

\section{Physiological testing and biomass determinations}

Coral tissue and zooxanthellae were removed from the coral skeleton with a Water-Pik and subsamples of the homogenate taken for zooxanthellae counts and chlorophyll $a$ determinations. The remaining homogenate was filtered through three layers of cheesecloth and centrifuged at $1500 \times g$ for $3 \mathrm{~min}$. The pellet was resuspended and washed (recentrifuged) with fresh filtered $(0.45 \mu \mathrm{m})$ seawater (FSW) at least three times, or until few animal fragments were seen amongst the zooxanthellae in microscopic observations.

Cleaned zooxanthellae were resuspended in FSW at densities between 0.5 and $1.0 \times 10^{6}$ zooxanthellae per milliliter. Respiration rates in the dark and photosynthetic rates at $450 \mu \mathrm{E} \mathrm{m}^{-2} \mathrm{~s}^{-1}$ (above saturation) were determined with a YSI oxygen meter equipped with low-volume (2$10 \mathrm{ml}$ ) chambers and magnetic stirrers. Respiration and net photosynthesis rates were added together to give gross photosynthesis rates and standardized to number of zooxanthellae. Gross photosynthesis:respiration (P:R) ratios were calculated from these rates.

Chlorophyll fluorescence of zooxanthellae suspensions was measured with a Turner fluorometer, after a 10-min incubation in darkness. The ratio of fluorescence obtained with additions of DCMU $\left(10^{-5} M\right)$ in relation to that without DCMU was calculated. Long-term kinetics of chlorophyll fluorescence of zooxanthellae living within the host were recorded with a pulse amplitude modulation fluorometer (model PAM 101, 103; Waltz). The corals were dark-adapted for $10 \mathrm{~min}$ under the fiber optic bundle of the fluorometer prior to measurement. The initial fluorescence $(\mathrm{Fo})$ was measured by exposing the coral to a weak pulse of red light $\left(<1 \mu \mathrm{E} \mathrm{m}^{2} \mathrm{~s}^{-1}\right)$. Maximum fluorescence $(\mathrm{Fm})$ was then determined by applying a 1 -s pulse of intense white light $\left(>500 \mu \mathrm{E} \mathrm{m}^{2} \mathrm{~s}^{-1}\right)$. The maximum variable fluorescence was calculated as $\mathrm{Fv}=\mathrm{Fm}-\mathrm{Fo}$. The value $\mathrm{Fv} / \mathrm{Fm}$ is used to indicate the photosynthetic efficiency and is proportional to the quantum yield.

Chlorophyll $a$ was extracted with acetone by the method of Jeffrey and Humphrey (1975). Total chlorophyll $a$ was calculated from absorbance at 663 and $630 \mathrm{~nm}$ and standardized per algal cell extracted.

Zooxanthellae densities were calculated from the total number of zooxanthellae and the surface area of the coral. Number of zooxanthellae was determined from replicate (8-10) hemacytometer counts. Surface area was determined by covering the surface of the coral with aluminum foil, weighing the foil, and applying a standard curve relating aluminum weight to area.

\section{Results}

\section{High-temperature stress in ambient light}

The response of corals and their symbiotic algae to hightemperature stress varied with species of coral, but followed a similar pattern (Figs. 1-4). The pattern is best illustrated with Montastrea annularis maintained at $32^{\circ} \mathrm{C}$ : photosynthetic rates and potential (fluorescence ratio $\mathrm{F}^{+\mathrm{DCMU}} / \mathrm{F}^{-\mathrm{DCMU}}$ ) as well as P:R (photosynthesis: respiration) ratio all decreased before any significant change in density of zooxanthellae was evident. At $34^{\circ} \mathrm{C}$ it took less than $24 \mathrm{~h}$ for photosynthesis, fluorescence ratios, and the P:R to decrease to 0 . The zooxanthellae density and chlorophyll $a$ content per zooxanthella changed little at $34^{\circ} \mathrm{C}$ before coral death was first observed at $19 \mathrm{~h}$. Zooxanthellae from $M$. annularis maintained at $30^{\circ} \mathrm{C}$ differed little from zooxanthellae isolated from freshly collected 
Montastrea annularis
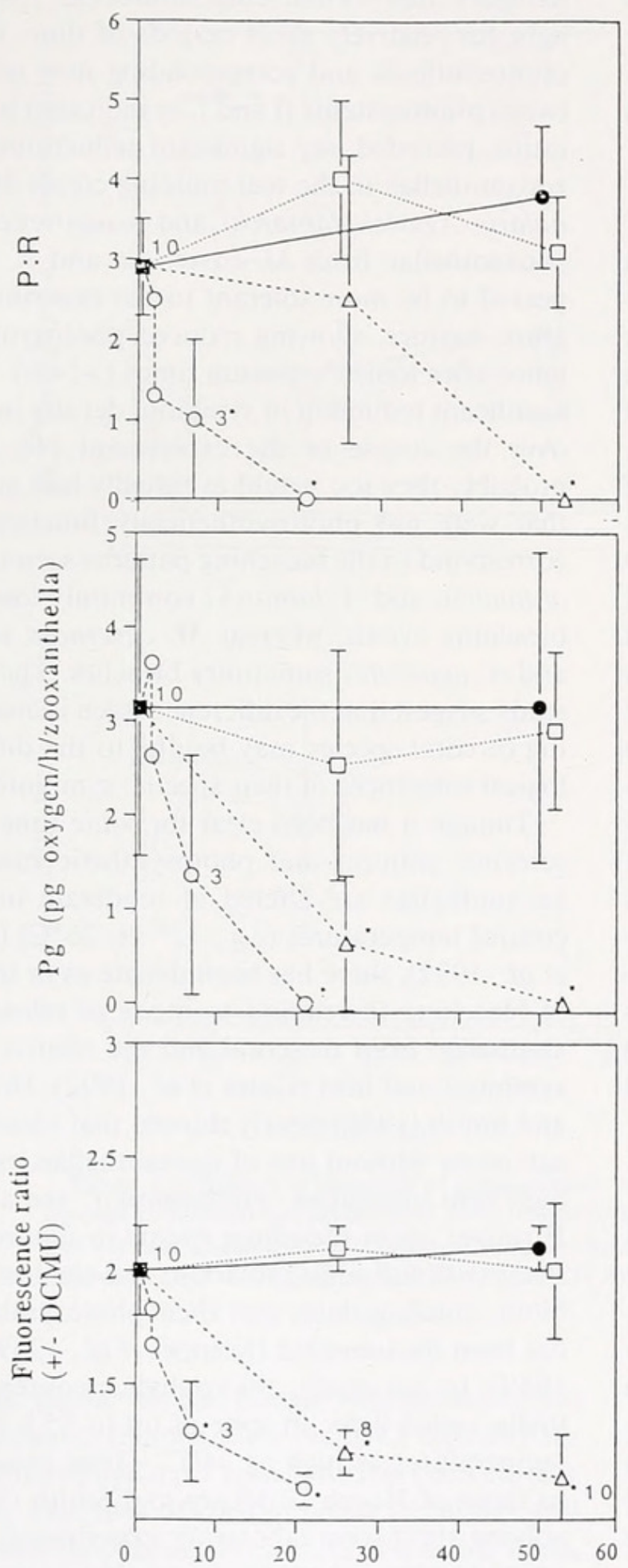

Time (h)
Montastrea cavernosa
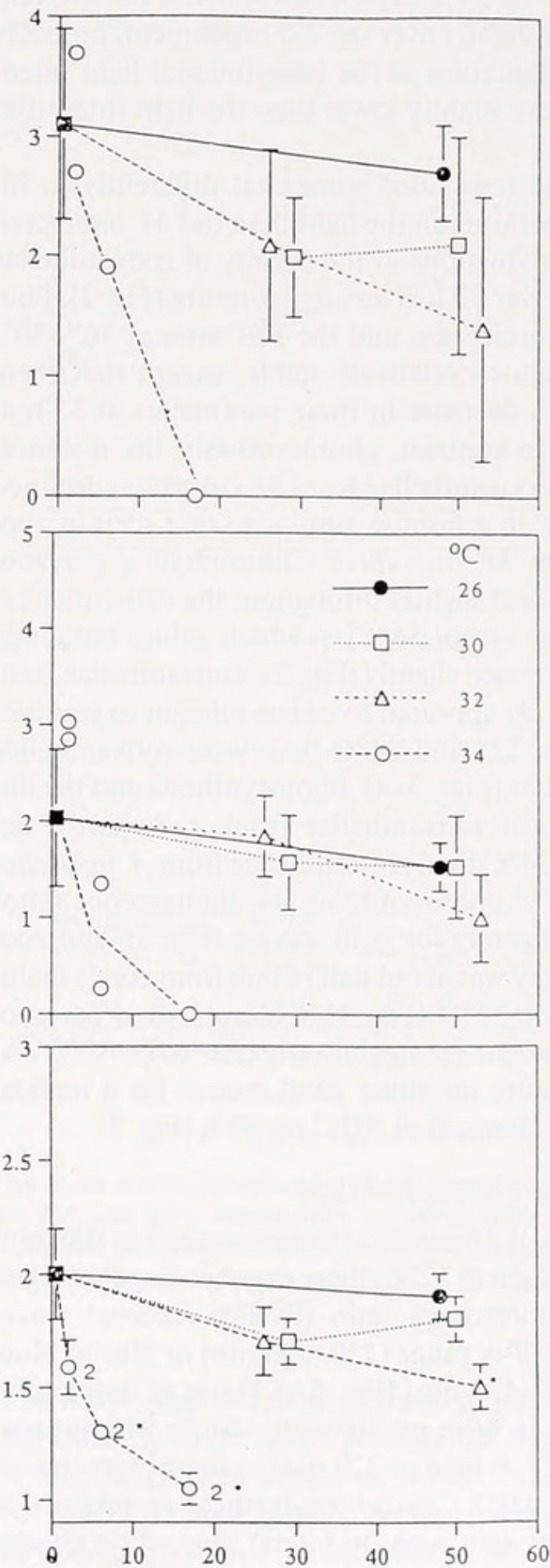

Figure 1. Patterns of bleaching of zooxanthellae in the corals Montastrea annularis and $M$. cavernosa exposed to seawater temperatures of $26^{\circ} \mathrm{C}$ (control), $30^{\circ}, 32^{\circ}$, and $34^{\circ} \mathrm{C}$ : gross photosynthesis: respiration ratio $(P: R)$, gross photosynthesis $\left(P_{g}\right)$, and fluorescence ratio $\left(F_{+D C M U} / F_{-D C M U}\right)$ in relation to exposure time. All data points are means $\pm \mathrm{SD}, n=4$, unless otherwise noted. ${ }^{*}=$ significantly $(P<0.05$, ANOVA $)$ different from controls. 
corals or those maintained at ambient seawater temperature $\left(26^{\circ} \pm 1^{\circ} \mathrm{C}\right)$ for 2 days. Chlorophyll $a$ per zooxanthella increased slightly over the 2-d experiment, probably due to photoadaptation to the experimental light intensities, which were slightly lower than the light intensities in situ (Fig. 2).

$M$. cavernosa responded somewhat differently to increases of temperature in the light than $\operatorname{did} M$. annularis. No significant reductions in the density of zooxanthellae were observed over $53 \mathrm{~h}$ at any temperature (Fig. 2). Photosynthesis, fluorescence, and the P:R ratio at $26^{\circ}, 30^{\circ}$, and $32^{\circ} \mathrm{C}$ remained relatively stable, except that there was a $25 \%-50 \%$ decrease in these parameters at $53 \mathrm{~h}$ at $32{ }^{\circ} \mathrm{C}$ (Fig. 1). In contrast, photosynthesis, fluorescence, and $\mathrm{P}: \mathrm{R}$ of the zooxanthellae from $M$. cavernosa declined rapidly at $34^{\circ} \mathrm{C}$ in a fashion similar to that seen in zooxanthellae from $M$. annularis. Chlorophyll $a$ per zooxanthella increased slightly throughout the experiment at all temperatures except $34^{\circ} \mathrm{C}$, at which values remained the same or decreased slightly (Fig. 2). Zooxanthellae from Agaracia lamarcki appeared to be less tolerant to seawater temperatures of $32^{\circ}$ and $34^{\circ} \mathrm{C}$ than were zooxanthellae from A. agaricites (Figs. 3-4). Photosynthesis and the fluorescence ratio of zooxanthellae from $A$. lamarcki declined faster at $34^{\circ} \mathrm{C}$ than zooxanthellae from $A$. agaricites (Fig. 3). At $32^{\circ} \mathrm{C}$, photosynthesis and fluorescence ratios decreased significantly for both species (Fig. 3), and zooxanthellae density was about half of that from corals maintained at $30^{\circ}$ or $26^{\circ} \mathrm{C}$ (Fig. 4). Chlorophyll $a$ per zooxanthella did not change significantly $(P>0.05$, ANOVA) at any temperature for either coral, except for a marked decrease for $A$. lamarcki at $32^{\circ} \mathrm{C}$ for $48 \mathrm{~h}$ (Fig. 4).

\section{High-temperature stress and light}

When pieces of $M$. annularis were exposed to different wavelengths of light at $32^{\circ} \mathrm{C}$, those experiencing the largest decrease in fluorescence ratio $(\mathrm{Fv} / \mathrm{Fo})$ received wavelengths in the UV-A range ( $320-400 \mathrm{~nm})$ or blue to bluegreen light (395-495 nm) (Fig. 5A). Rates of decrease in fluorescence ratio were no different with or without natural levels of UV-B light $(<320 \mathrm{~nm})$ in these experiments (ANOVA, $P>0.05$ ). Control corals (those maintained at $26^{\circ} \mathrm{C}$ in natural light with no filters) showed no change in fluorescence ratio throughout the experiment.

Fluorescence ratios $(\mathrm{Fv} / \mathrm{Fo})$ of intact $M$. annularis exposed to $32^{\circ} \mathrm{C}$ declined faster when exposed to higher intensity than lower intensity of natural light (Fig. 5B). Interestingly, a "recovery" trend was observed in the same experiment and in three similar experiments (not included) during periods of cloudy weather.

\section{Discussion}

This study shows that symbiotic dinoflagellates living inside of reef corals exhibit a marked decline in their pho- tosynthetic capacity and oxygen evolution when exposed to higher than normal temperatures $\left(32^{\circ}, 34^{\circ} \mathrm{C}\right)$ in natural light for relatively short periods of time. Reductions in photosynthesis and corresponding flow of electrons between photosystems II and I, as indicated by fluorescence ratios, preceded any significant reductions in density of zooxanthellae in the reef-building corals Montastrea annularis, Agaricia lamarcki, and A. agaricites. In addition, zooxanthellae from $M$. cavernosa and $A$. agaricites appeared to be more tolerant to the experimental temperature regimes, showing reduced photosynthetic competence after longer exposure times $(>24 \mathrm{~h})$. There was no significant reduction in symbiont density in $M$. cavernosa over the course of the experiment $(48-55 \mathrm{~h})$, though probably they too would eventually lose symbiotic algae that were not photosynthetically functional. The data correspond to the bleaching patterns seen in the field; $M$. annularis, and $A$. lamarcki commonly lose color during bleaching events, whereas $M$. cavernosa rarely bleaches and $A$. agaricites sometimes bleaches. The results of this study suggest that the differences seen in nature in bleaching of coral species may be due to the different physiological tolerances of their specific symbiotic algae.

Though it has been clear for some time that the fluorescence patterns and photosynthetic rates of cultured zooxanthellae are altered at moderate increases above control temperatures (e.g., $32^{\circ}$ vs. $26^{\circ} \mathrm{C}$ ) (Iglesias-Prieto et al., 1992), there has been debate as to the mechanism of bleaching in relation to mode of release of the zooxanthellae from the coral and the relative health of the symbiont and host (Gates et al., 1992). Hoegh-Guldberg and Smith (1989) clearly showed that bleaching of corals can occur without loss of zooxanthellae, especially when high light intensities "photo-bleach" the algal pigments. However, most bleaching events in nature involve heat stress with full solar radiation, and the loss of both symbiotic dinoflagellates and their photosynthetic pigments has been documented (Kleppel et al., 1989; Porter et al., 1989). In our study, chlorophyll $a$ content per zooxanthella varied little, in spite of up to $55 \mathrm{~h}$ of exposure to temperatures as high as $34^{\circ} \mathrm{C}$. These results are similar to those of Hoegh-Guldberg and Smith (1989), also involving short-term laboratory experiments on corals exposed to elevated temperatures, but in contrast to field observations made during natural bleaching events in the Virgin Islands and southern Florida which showed reductions of chlorophyll $a$ ranging from $50 \%$ to $80 \%$ (Porter et al., 1989; Kleppel et al., 1989). The only reductions seen in chlorophyll content in this study occurred at $34^{\circ} \mathrm{C}$ at longer exposure times, suggesting that pigment loss during bleaching occurs after physiological damage to photosynthesis. During short-term (days) laboratory experiments, zooxanthellae from the more sensitive symbioses appear to leave the host before or during loss of 
Montastrea annularis
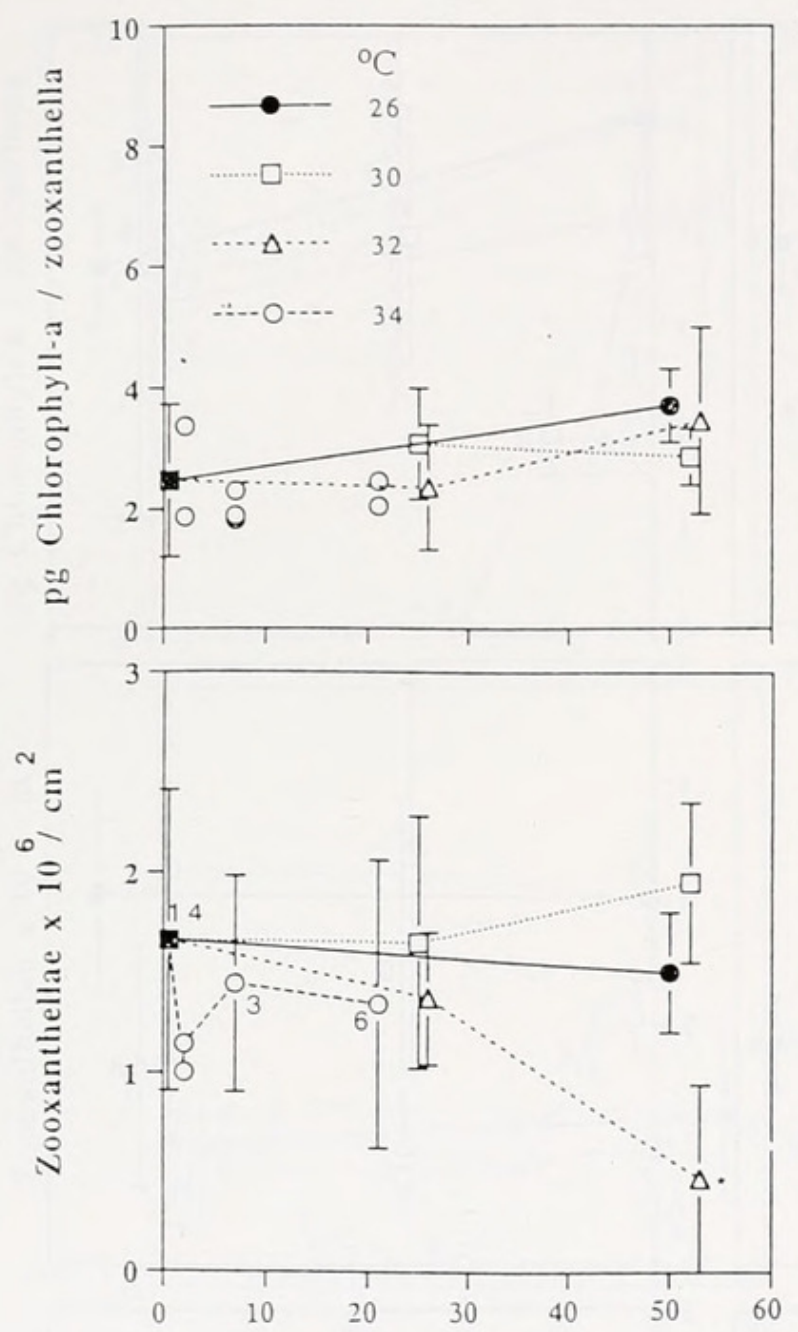

Time (h)
Montastrea cavernosa
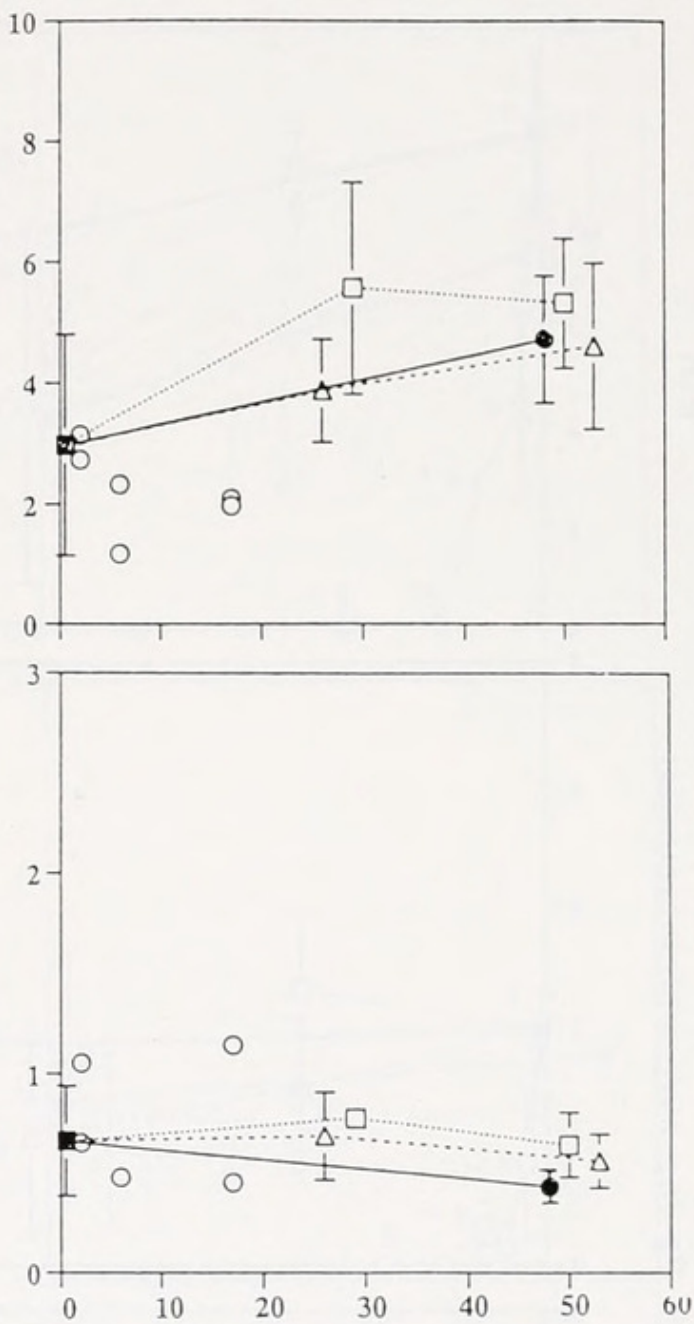

Time (h)

Figure 2. Patterns of bleaching of zooxanthellae in the corals Montastrea anmularis and $M$. cavernosa exposed to seawater temperatures of $26^{\circ} \mathrm{C}$ (control), $30^{\circ}, 32^{\circ}$, and $34^{\circ} \mathrm{C}$ : chlorophyll $a$ per zooxanthella and zooxanthella density in relation to exposure time. All data points are means $\pm \mathrm{SD}, n=4$, unless otherwise noted. ${ }^{*}=$ significantly $(P<0.05$, ANOVA $)$ different from controls.

photosynthetic pigmentation. Longer exposures (weeks) to elevated seawater temperatures $\left(\geq 30^{\circ} \mathrm{C}\right)$ typically involve loss of chlorophyll $a$ per zooxanthellae co-occurring with relatively low rates of zooxanthellae expulsion and a decrease in density of zooxanthellae (Glynn and D'Croz, 1990). Thus, loss of photosynthetic pigments appears to be a normal step in warm-water bleaching in nature, and one that indicates algal stress.

When Hoegh-Guldberg and Smith (1989) used chlorophyll data taken from water surrounding the corals to calculate release rates of zooxanthellae from the heatstressed $\left(30^{\circ}, 32^{\circ} \mathrm{C}\right)$ Pacific corals Stylophora pistillata and Seriatopora hystrix, expulsion rates increased by a factor of 2 to 10 , but only the corals maintained at $32^{\circ} \mathrm{C}$ showed significant decreases in density of zooxanthellae. In the present study, zooxanthellae density in Montastrea annularis, Agaricia lamarcki, and A. agaricites decreased significantly only after photosynthesis and enhanced zooxanthellar fluorescence decreased. Zooxanthellae from M. cavernosa were apparently more resistant to the higher temperatures than zooxanthellae in $M$. annularis, in that zooxanthellae density did not change over the 2 days of exposure to $32^{\circ} \mathrm{C}$. However, at least some of the zooxanthellae in $M$. cavernosa held 2 days at $32^{\circ} \mathrm{C}$ showed reduced photosynthetic capacity, and-on the basis of the experiments with $M$. annularis-densities might be expected to decrease after longer exposure times. Similarly, Glynn and D'Croz (1990), who documented steady decreases in density of zooxanthellae from Pocillopora damicornis at $30^{\circ}$ and $32^{\circ} \mathrm{C}$, found that the effects were evident (significantly different from controls) only after 2 weeks or more. 
Agaricia lamarcki
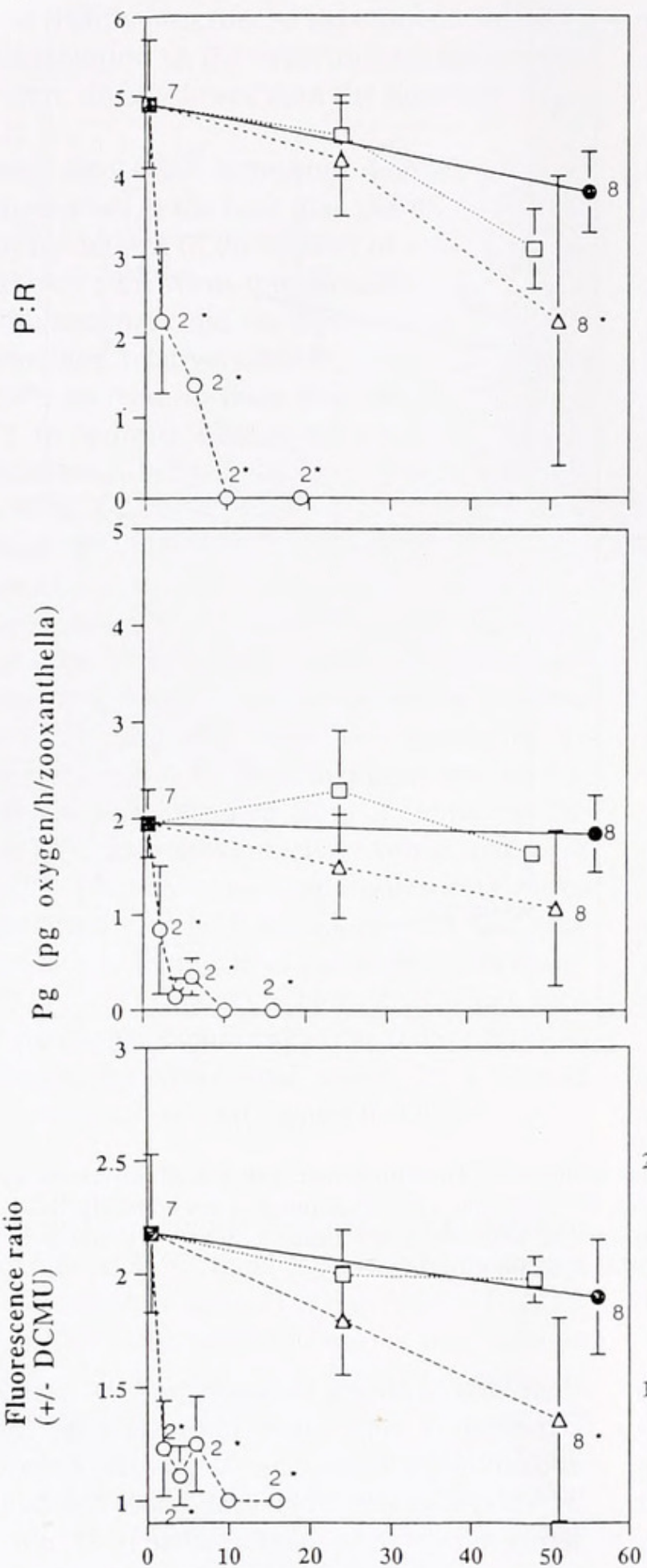

Time $(h)$
Agaricia agaricites
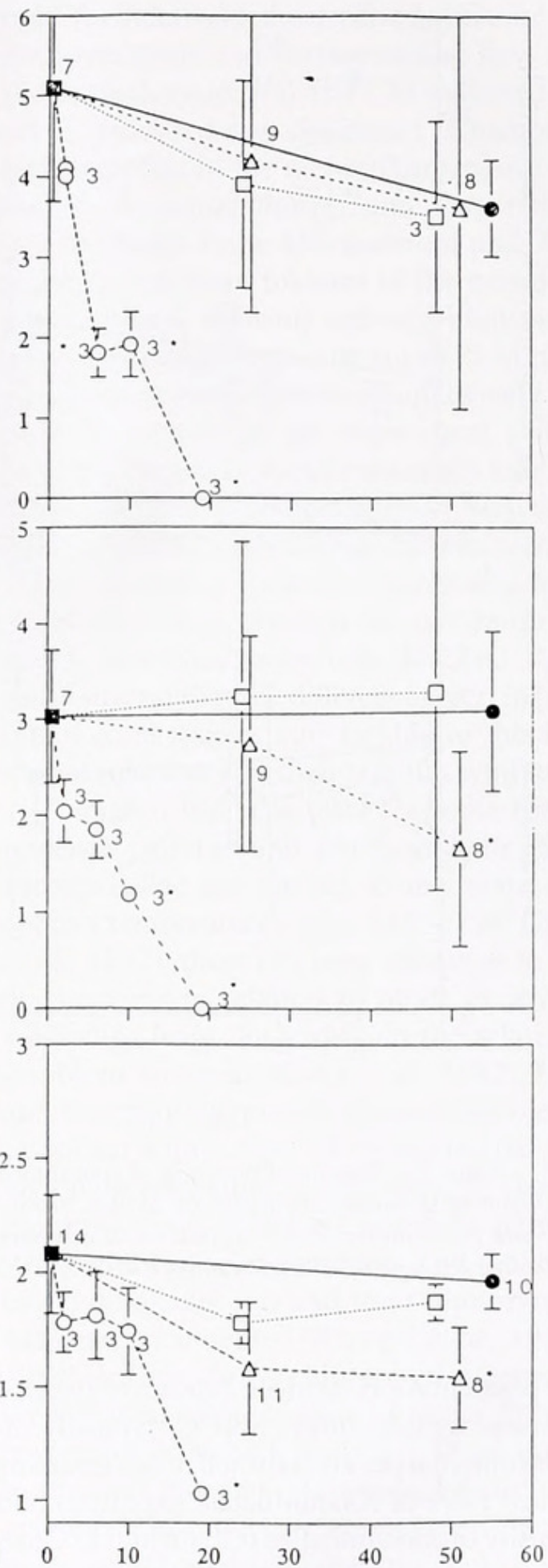

Figure 3. Patterns of bleaching of zooxanthellae in the corals Agaricia agaricites and A. lamarckii exposed to seawater temperatures of $26^{\circ} \mathrm{C}$ (control), $30^{\circ}, 32^{\circ}$, and $34^{\circ} \mathrm{C}$ : gross photosynthesis: respiration ratio (P: $\mathrm{R})$, gross photosynthesis $\left(\mathrm{P}_{\mathrm{g}}\right)$, and fluorescence ratio $\left(\mathrm{F}_{+\mathrm{DCMU}} / \mathrm{F}_{-\mathrm{DCMU}}\right)$ in relation to exposure time. All data points are means \pm SD., $n=4$, unless otherwise noted. ${ }^{*}=$ significantly $(P<0.05$, ANOVA $)$ different from controls. Symbols as in Figures 1 and 2. 
Agaricia lamarcki
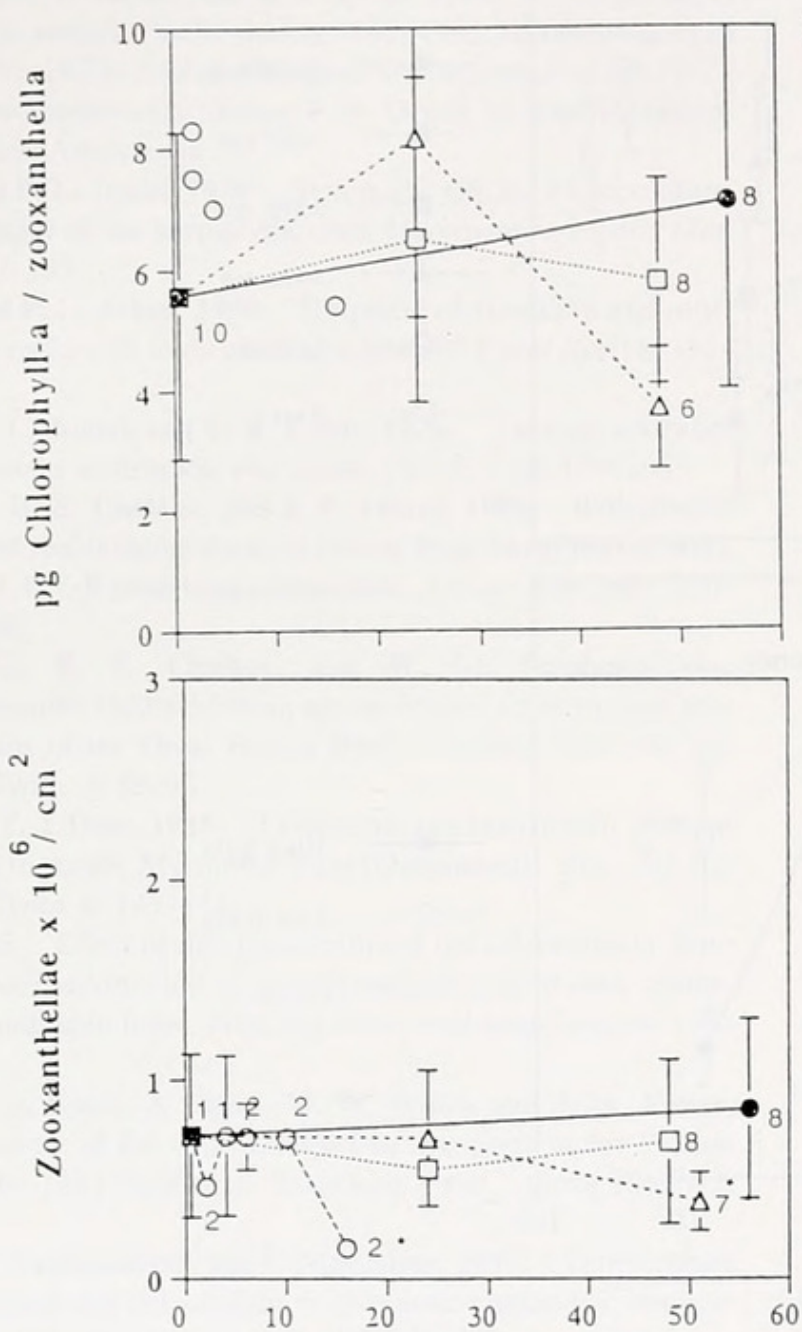

Time (h)
Agaricia agaricites
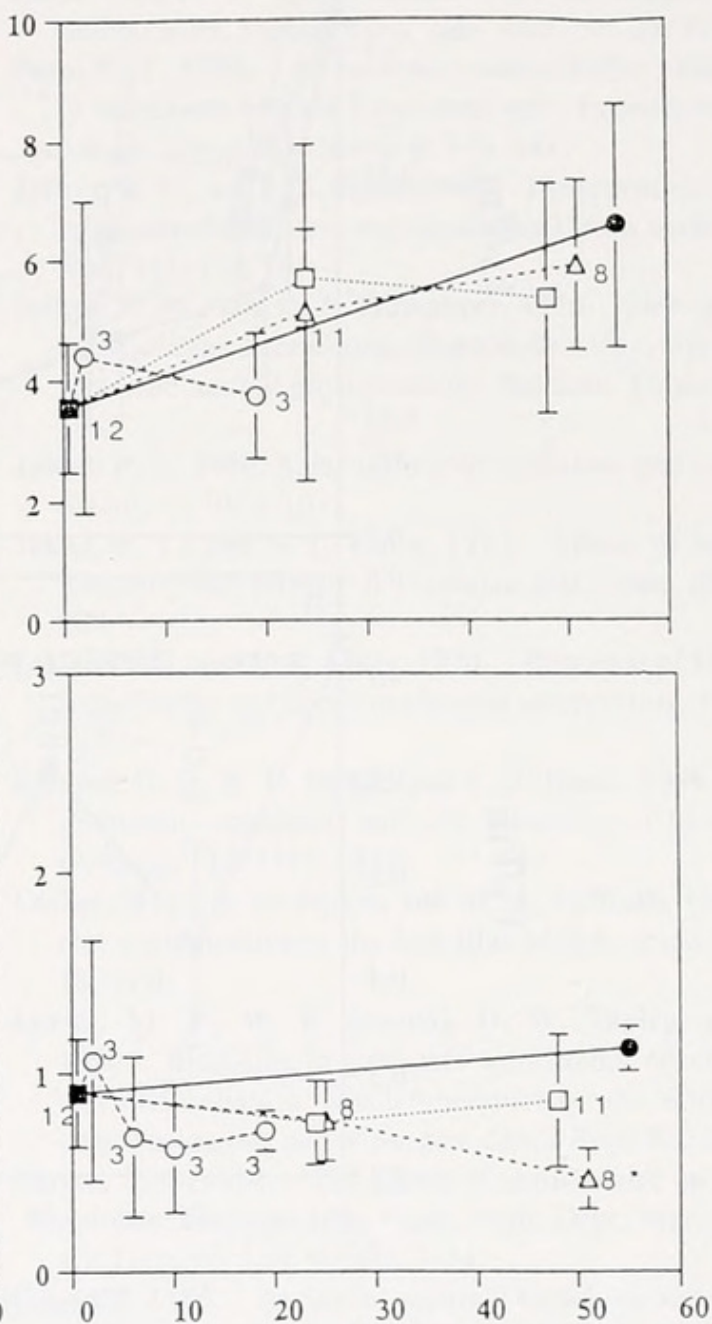

Time (h)

Figure 4. Patterns of bleaching of zooxanthellae in the corals Agaricia agaricites and A. lamarckii exposed to seawater temperatures of $26^{\circ} \mathrm{C}$ (control), $30^{\circ}, 32^{\circ}$, and $34^{\circ} \mathrm{C}$ : chlorophyll $a$ per zooxanthella and zooxanthella density in relation to exposure time. All data points are means $\pm \mathrm{SD}, n=4$, unless otherwise noted. ${ }^{*}=$ significantly $(P<0.05$, ANOVA $)$ different from controls. Symbols as in Figures 1 and 2.

Light and dark rates of zooxanthellar expulsion are identical in Stylophora pistillata and Seriatopora hystrix maintained at ambient temperature (Hoegh-Guldberg and Smith, 1989). In contrast, corals maintained at high temperatures in the light exhibit higher rates of expulsion (Hoegh-Guldberg and Smith, 1989), resulting in reduced densities of zooxanthellae at $32^{\circ} \mathrm{C}$ (Hoegh-Guldberg and Smith, 1989; this study). The quantity of light makes a major difference in the kinetics of warm-water-induced bleaching; zooxanthellae kept in dim light take longer, and often require higher temperatures, to achieve the same level of bleaching as seen in brighter light (Fig. 2 this study, Warner and Fitt, unpub.). The quality of light is also a factor in bleaching. Although the effects of large and sudden increases in UV-B can be devastating to zooxanthellae in corals (Lesser et al., 1990; Gleason and Wellington,
1993), most shallow-water corals have UV-protective mycosporine-like amino acids (MAAs) that screen out such dangerous wavelengths. Much more likely sources of synergistic light energy for bleaching are longer wavelength UV-A (wavelengths not screened out by MAAs) and blue light, both important in photosynthesis and therefore not screened out by the coral host (Dunlap et al., 1988). Preliminary experiments show that blue light also promotes bleaching of some types of cultured zooxanthellae much more effectively than the same amount of light at any other part of the visible spectrum (Fitt and Warner, unpub.).

It is not clear at present whether coral death is solely a function of animal tissue death, or if lack or dysfunction of zooxanthellae may trigger or exacerbate events preceding host tissue sloughing and coral death. That the latter 


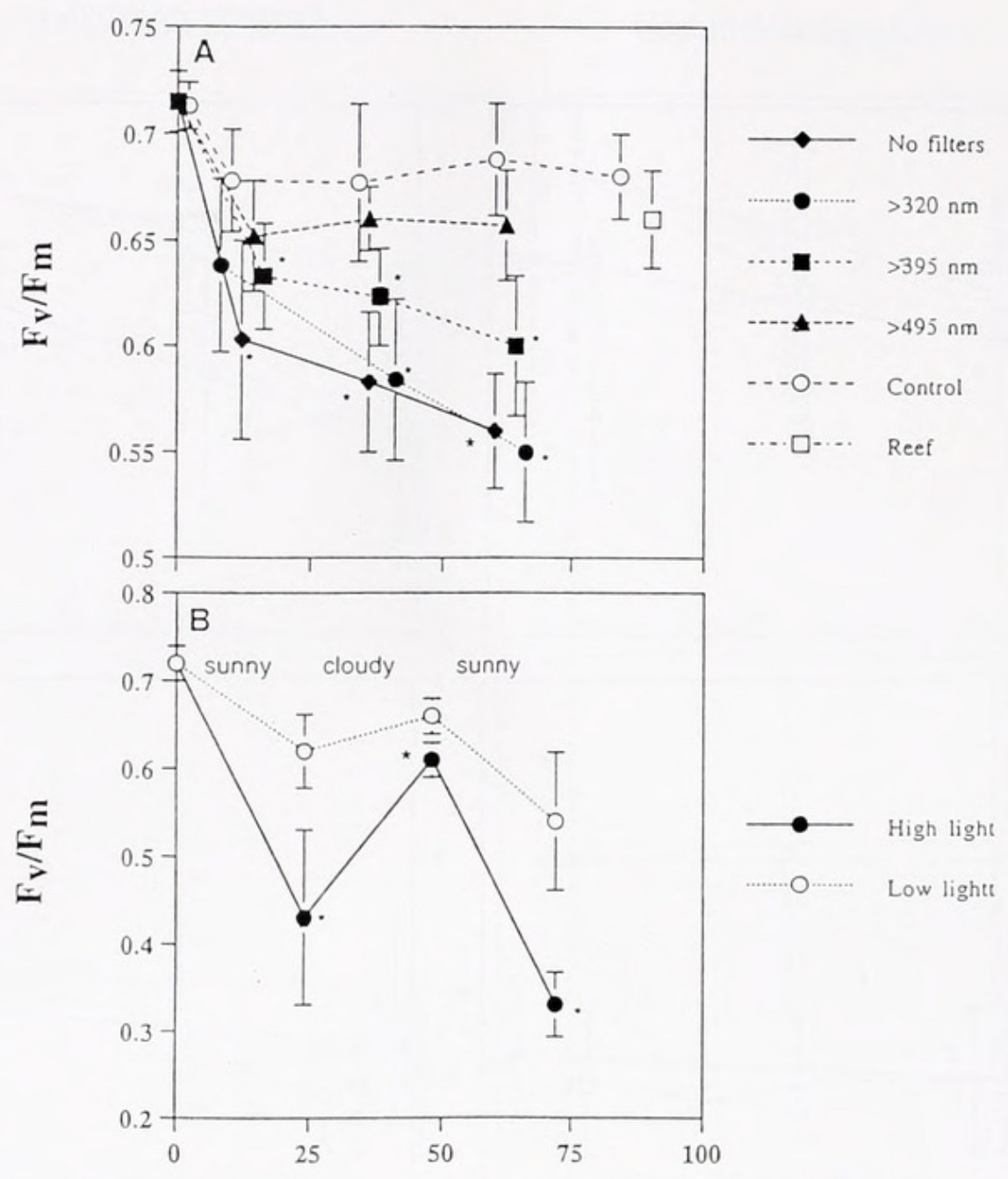

Time (h)

Figure 5. Fluorescence ratios $\left(\mathrm{F}_{\mathrm{m}} / \mathrm{F}_{\mathrm{o}}\right)$ of zooxanthellae in Montastrea annularis collected from the reef $\left(28^{\circ} \mathrm{C}\right.$ ) or exposed to seawater temperatures of $26^{\circ} \mathrm{C}$ (control) and $32^{\circ} \mathrm{C}$ (all other data) under different wavelengths (A) and intensities (B) of natural light in relation to exposure time. Neutral-density screens were used to adjust maximum intensities to $54 \%$ of air ambient (high light) in all experiments. Cut-off filters were used to adjust wavelength (A), and additional neutral-density screens reduced ambient light to $19 \%$ of air ambient (low light) in (B). All data points are means $\pm \mathrm{SD}, n=6 .{ }^{*}=$ significantly different from control (A, ANOVA) or low light intensities (B, Student's $t$ test).

can occur in nature was illustrated, on a somewhat longer time scale, in the Eastern Pacific after extensive coral bleaching during the El Niño Southern Oscillation (ENSO) event of 1982-1983 (Glynn, 1983, 1984). Before the widespread local and regional deaths of the corals, no zooxanthellae remained in the tissues of Pocillopora damicornis and Millepora spp. Temperatures only a few degrees above normal ambient will kill reef corals. Mayer (1914) found that all the reef corals tested in the Dry Tortugas, at the end of the Florida reef tract, died when exposed for an hour to temperatures between $36^{\circ}$ and $38^{\circ} \mathrm{C}$ during the summer. In this early study, the organisms that died at the lowest temperatures tested (M. annularis, A. lamarcki, and the hydrocoral Millepora sp.) are the same species that are the first to react during natural bleaching events (e.g., Williams and Bunkley-Wil- liams, 1988), lending support to the notion that the differential bleaching of zooxanthellate cnidarians exposed to moderately high temperatures in nature reflects the tolerances of their particular zooxanthellae.

\section{Acknowledgments}

We thank Drs. R. Smith and G. Schmidt for technical assistance during portions of this study, and W. Wiebe for comments on the manuscript. This research was partially supported by grants from NSF (OCE 9203327, OCE 9349773), ONR (N00014-92-J-1734), and NOAA (CMRC 95-3041). Contribution \#2 from the Key Largo Marine Research Laboratory and \#575 from the Discovery Bay Marine Laboratory. 


\section{Literature Cited}

Coffroth, M. A., H. R. Lasker, and K. J. Oliver. 1990. Coral mortality outside of the eastern Pacific during 1982-1983: relationship to El Niño. Pp. 141-182 in Global Ecological Consequences of the 1982 1983 El Niño-Southern Oscillation, P. W. Glynn, ed. Elsevier Oceanography Series, Amsterdam.

Coles, S. L., and P. L. Jokiel. 1978. Synergistic effects of temperature, salinity and light on the hermatypic coral Montipora verrucosa. Mar. Biol. 49: 187-195

Coles, S. L., and P. L. Jokiel. 1990. Response of Hawaiian and other Indo-Pacific reef corals to elevated temperature. Coral Reefs 8: 155 162.

Coles, S. L., P. L. Jokiel, and C. R. Lewis. 1976. Thermal tolerance in tropical versus subtropical reef corals. Pac. Sci. 30: 159-166.

Dunlap, W. C., B. E. Chalker, and J. K. Oliver. 1986. Bathymetric adaptations of reef-building corals at Davies Reef, Great Barrier Reef. Australia. III. UV-B absorbing compounds. J. Exp. Mar. Biol. Ecol. 104: $239-248$.

Dunlap, W. C., B. E. Chalker, and W. M. Bandaranayake. 1988. Ultraviolet light absorbing agents derived from tropical marine organisms of the Great Barrier Reef, Australia. Proc. 6th Int. Coral Reef Symp. 3: 89-93.

Fisk, D. A., and T. J. Done. 1985. Taxonomic and bathymetric patterns of bleaching in corals, Myrmidon Reef (Queensland). Proc. 5th Int. Coral Reef Symp. 6: 149-154.

Fitt, W. K. 1985. Effect of different strains of the zooxanthella Symbiodinium microadriaticum on growth and survival of their coelenterate and molluscan hosts. Proc. 5th Intl. Coral Reef Symp. 6: 131 136.

Fitt, W. K., H. J. Spero, J. Halas, M. W. White, and J. W. Porter. 1993. Recovery of the coral Montastrea annularis in the Florida Keys after the 1987 Caribbean "bleaching event." Coral Reefs 12: $57-64$.

Gates, R. D., G. Baghdasarian, and L. Muscatine. 1992. Temperature stress causes host cell detachment in symbiotic cnidarians: implications for coral bleaching. Biol. Bull. 182: 324-332.

Gleason, D. F., and G. M. Wellington. 1993. Ultraviolet radiation and coral bleaching. Nature 365: 836-838.

Glynn, P. W. 1983. Extensive "bleaching" and death of reef corals on the Pacific coast of Panama. Environ. Conserv. 10: 149-154.

Glynn, P. W. 1984. Widespread coral mortality and the 1982/83 El Niño warming event. Environ. Conserv. 11: 133-146.

Glynn, P. W., and L. D'Croz. 1990. Experimental evidence for high temperature stress as the cause of El Niño-coincident coral mortality. Coral Reefs 8: 181-191.

Harriott, V. J. 1985. Mortality rates of scleractinian corals before and during a mass bleaching event. Mar. Ecol. 21: 81-88.

Hoegh-Guldberg, O., and G. J. Smith. 1989. The effect of sudden changes in temperature, light and salinity on the population density and export of zooxanthellae from the reef corals Stylophora pistillata Esper and Seriatopora hystrix Dana. J. Exp. Mar. Biol. Ecol. 129: 279-303.

Iglesias-Prieto, R., J. L. Matta, W. A. Robins, and R. K. Trench. 1992. Photosynthetic response to elevated temperature in the sym- biotic dinoflagellate Symbiodinium microadriaticum in culture. Proc Natl. Acad. Sci. 89: 10302-10305.

Jaap, W. C. 1979. Observations on zooxanthellae expulsion at Middle Sambo Reef, Florida Keys. Bull. Mar. Sci. 29: 414-422.

Jaap, W. C. 1985. An epidemic zooxanthellae expulsion during 1983 in the Lower Florida Keys coral reefs: hyperthermic etiology. Proc. 5th Int. Coral Reef Symp. 6: 143-148.

Jeffrey, S. W., and F. T. Haxo. 1968. Photosynthetic pigments of symbiotic dinoflagellates (zooxanathellae) from corals and clams. Biol. Bull. 135: 139-165.

Jeffrey, S. W., and G. F. Humphrey. 1975. New spectrophotometric equations for determining chlorophylls $a, b, c_{1}$ and $c_{2}$ in higher plants, algae and natural phytoplankton. Biochem. Physiol. Planz. 167: 191194.

Jokiel, P. L. 1980. Solar ultraviolet radiation and coral reef epifauna. Science 7: 1069-1071

Jokiel, P. L., and S. L. Coles. 1977. Effects of temperature on the mortality and growth of Hawaiian reef corals. Mar. Biol. 43: 201208.

Jokiel, P. L., and S. L. Coles. 1990. Response of Hawaiian and other Indo-Pacific reef corals to elevated temperature. Coral Reefs 8: $155-$ 162.

Kleppel, G. S., R. E. Dodge, and C. J. Reese. 1989. Changes in pigmentation associated with the bleaching of stony corals. Limnol. Oceanogr. 34: 1331-1335

Lasker, R. L., E. C. Peters, and M. A. Coffroth. 1984. Bleaching of reef coelenterates in the San Blas Islands, Panama. Coral Reefs 3: 183-190.

Lesser, M. P., W. R. Stochaj, D. W. Tapley, and J. M. Shick. 1990. Bleaching in coral reef anthozoans: effects of irradiance, ultraviolet radiation, and temperature on the activities of protective enzymes against active oxygen. Coral Reefs 8: 225-232.

Mayer, A. G. 1914. The effects of temperature upon tropical marine animals. Carnegie Inst. Wash. Publ. Dept. Mar. Biol., Papers from the Tortugas Lab. 6(183): 3-24.

Oliver, J. 1985. Recurrent seasonal bleaching and mortality of corals on the Great Barrier Reef. Proc. 5th Int Coral Reef Symp 6: 201206.

Porter, J. W., and O. Meier. 1992. Quantification of loss and change in Floridean reef coral population. Am. Zool. 32: 625-640.

Porter, J. W., W. K. Fitt, H. J. Spero, C. S. Rogers, and M. W. White. 1989. Bleaching in reef corals: physiological and stable isotopic responses. Proc. Natl. Acad. Sci. 86: 9342-9346.

Szmant, A. M., and N. J. Gassman. 1990. The effects of prolonged "bleaching" on the tissue biomass and reproduction of the reef coral Montastrea annularis. Coral Reefs 8: 217-224.

Trench, R. K. 1993. Microalgal-invertebrate symbioses: a review. Endocytobiosis Cell Res. 9: 135-175.

Williams, E. H., and L. Bunkley-Williams. 1988. Circumtropical coral reef bleaching in 1987-1988. Proc. 6th Coral Reef Symp. 3: 313318.

Yonge, C. M., and A. G. Nichols. 1931. Studies on the physiology of corals. V. The effect of starvation in light and darkness on the relationship between corals and zooxanthellae. Sci. Rept. Great Barrier Reef Exped. 1928-1929 1: 177-211 


\section{$2 \mathrm{BHL}$ Biodiversity Heritage Library}

Fitt, William K and Warner, M. E. 1995. "Bleaching Patterns of Four Species of Caribbean Reef Corals." The Biological bulletin 189, 298-307. https://doi.org/10.2307/1542147.

View This Item Online: https://www.biodiversitylibrary.org/item/17166

DOI: https://doi.org/10.2307/1542147

Permalink: https://www.biodiversitylibrary.org/partpdf/19929

\section{Holding Institution}

MBLWHOI Library

\section{Sponsored by}

MBLWHOI Library

\section{Copyright \& Reuse}

Copyright Status: In copyright. Digitized with the permission of the rights holder.

License: http://creativecommons.org/licenses/by-nc-sa/3.0/

Rights: https://biodiversitylibrary.org/permissions

This document was created from content at the Biodiversity Heritage Library, the world's largest open access digital library for biodiversity literature and archives. Visit BHL at https://www.biodiversitylibrary.org. 